\title{
Influence of Different Combinations of Media and Bio Fertilizers on Growth of Gerbera cv. Natasha under Protected Conditions
}

\author{
N. Swarupa ${ }^{1}$, D. Lakshminarayana ${ }^{1}$, P. Prasanth ${ }^{1}$ and D. Saida Naik ${ }^{2}$ \\ ${ }^{1}$ Department of Floriculture and Landscaping, College of Horticulture, Mojerla, SKLTS \\ Horticultural University, Rajendranagar, Hyderabad - 500032, India \\ ${ }^{2}$ Department of Crop Physiology, PJTS Agricultural University, Rajendranagar, \\ Hyderabad - 500032, India \\ *Corresponding author
}

Keywords

Gerbera, Media, Bio fertilizers, cv.Natasha

\section{Article Info}

Accepted:

20 March 2019

Available Online:

10 April 2019

\section{A B S T R A C T}

The present investigation entitled "Studies on the effect of different combinations of media and bio fertilizers on growth, flowering and cut flower yield of gerbera (gerbera jamsonii L.) cv. Natasha under protected conditions". The whole experiment was arranged over 10 treatments consisting of five levels of media combinations, $\mathrm{M}_{1}-$ Red soil + Coco peat (1:1), $\mathbf{M}_{2}$ - Red soil + Vermicompost (1: 1), $\mathbf{M}_{3}$ - Red soil + Coco peat + Vermicompost $(1: 1: 1), M_{4}-$ Red soil + Coco peat + Vermicompost (2:1:1) and $\mathbf{M}_{5}-$ Control (Red soil only) with two levels of bio fertilizers $\mathrm{B}_{1}$ - PSB (Phosphate Solubilizing Bacteria) and $\mathrm{B}_{2}$ VAM (Vesicular Arbuscular Mycorrhiza). Interaction between different media combinations and bio fertilizers had significant influence on growth parameters and root parameters. $\mathrm{M}_{3}$ combination of media [Red soil + Coco peat + Vermicompost (1:1:1)] and $\mathrm{B}_{2}$ bio fertilizer, Vesicular Arbuscular mycorrhiza (VAM) registered significantly maximum plant height at first flower appearance $(22.27 \mathrm{~cm})$, plant height at flower harvesting stage $(24.97 \mathrm{~cm}$ ), wider plant spread at first flower appearance East - West direction $(51.92 \mathrm{~cm})$ and North - South direction $(54.94 \mathrm{~cm})$, higher plant spread at flower harvesting stage East - West direction $(53.98 \mathrm{~cm})$ and North - South direction $(57.94 \mathrm{~cm})$, more number of leaves per plant $(37.29 \mathrm{~cm})$, broader leaf area at final harvest $(120.45$ $\mathrm{cm}^{2}$ ), more number of roots per plant (60.29), highest length of the primary root $(53.29$ $\mathrm{cm})$, maximum value of plant fresh weight $(202.78 \mathrm{~g})$ and highest root to shoot ratio value $(0.93 \%)$.

\section{Introduction}

Gerbera is one of the herbaceous dwarf perennial plant, grows in clump with solitary flower heads on long slender stalks. It belongs to the family asteraceae and is native to South
Africa. It is popularly known as barberton, Transvaal and African (daisy). Gerbera is a popular cut flower grown throughout the world and its flowers are available in a wide range of colors including yellow, red, orange, cream, white, pink, brick red, scarlet, salmon 
peach, maroon and various other intermediate shades. Gerbera is an elegant flower of immense value as they are very attractive in garden with their star like flowers and borns terminally on slender long stems. It is very much suitable for making bouquets and flower arrangements since a leafless feature. Moreover it forms an effective colourful borders or beds. Gerbera is an ideal flower widely used as a cut flower besides for beds, pots, borders and rock gardens.

Gerbera is grown commercially in the Telangana state under naturally ventilated polyhouses. The total area under polyhouse cultivation in Telangana is about 1500 acres and more than 90 per cent of area is under Gerbera cultivation.

Different factors affect the growth and development of gerbera plants. Among them, potting media is one of the most important factors which plays a key role in better plant growth. A potting media must serves four functions viz., providing of moisture, supply of nutrients, permits gas exchange to the roots and support to the plants. Soil alone as a growing media does not fulfill all requirements for better growth and development of any crop. Gerbera grows well in substrates such as coco peat, sawdust, vermicompost, FYM, rice husk etc. Soil is not considered as a good option as growing media.

Cocopeat was gaining acceptance as a growing medium, because of its excellent aeration, durability, lightness and good water holding characteristics. The presence of organic compounds in coco peat can stimulate root growth and offer some natural resistance to plant diseases.

Vermicompost is an excellent soil conditioning agent and its incorporation to soil improves texture, structure, permeability, water holding capacity and proliferation of micro-organisms which enhanced better plant growth, root growth. Vermicompost contains 1.9, 2.0 and 0.8 per cent of $\mathrm{N}, \mathrm{P}, \mathrm{K}$ respectively. It also acts as chelating agent and regulates the availability of metabolic micronutrients like iron and zinc to the plants and increases the plant growth by providing nutrients in the available form.

Vesicular Arbuscular Mycorrhiza (VAM) is a fungi, can form a symbiosis with host plant. It stimulates growth and development of plants, increases absorption of plant immobile elements, reduces disease incidence. Keeping these points in view the present work was designed to study the effect of different combinations of media and bio fertilizers on growth, flowering and cut flower yield of gerbera (Gerbera jamesonii L.) under protected conditions.

\section{Materials and Methods}

A Gerbera (Gerbera jamsonii L.) cv. Natasha was taken for the investigation during the Rabi season of the year 2017. The experiment was carried out under naturally ventilated polyhouse at post graduate research block, College of Horticulture - Mojerla, SKLTS Horticultural University, Hyderabad (Telangana) and the site is situated at $78^{\circ} 29^{\prime}$ East longitude and $17^{\circ} 19^{\prime}$ North latitude with an altitude of $542.3 \mathrm{~m}$ above mean sea level. The location is characterized by semi-arid climate.

The experiment was laid out in a Factorial Randomized Block Design (FRBD) with three replications. The whole experiment was arranged over 10 treatments consisting of five levels of different combinations of media $\mathrm{M}_{1}$ Red soil + Coco peat (1:1), $\mathrm{M}_{2}-$ Red soil + Vermicompost (1: 1) $\mathrm{M}_{3}$ - Red soil + Coco peat + Vermicompost (1:1:1), $\mathrm{M}_{4}$ - Red soil + Coco peat + Vermicompost $(2: 1: 1) \mathrm{M}_{5}$ - 
Control (Red soil only) with two levels of bio fertilizers $B_{1}$ - PSB (Phosphate Solubilizing Bacteria) and $\mathrm{B}_{2}$ - VAM (Vesicular Arbuscular Mycorrhiza). Experiment was carried out in earthen pots having dimensions of $20 \mathrm{~cm}$ height and $30 \mathrm{~cm}$ diameter. Tissue cultured plants of gerbera cv. Natasha were used as planting material and planted one plant per each pot. The data on various parameters viz., Plant height at first flower appearance $(\mathrm{cm})$, Plant height at flower harvesting stage $(\mathrm{cm})$, Plant spread at first flower appearance EastWest direction $(\mathrm{cm})$, Plant spread at first flower appearance North-South direction (cm), Plant spread at flower harvesting stage East-West direction $(\mathrm{cm})$, Plant spread at flower harvesting stage North-South direction (cm), Number of leaves per plant, Leaf area at final harvest $\left(\mathrm{cm}^{2}\right)$, Number of roots per plant, Length of the primary root $(\mathrm{cm})$, Fresh weight of the plant $(\mathrm{g})$ and Root to shoot ratio $(\%)$. Parameters were recorded on five tagged plants and the mean values were subjected to statistical analysis as per Panse and Sukhatme (1985).

\section{Results and Discussion}

The data regarding to various growth and root parameters were statistically analyzed to test their significance and results of these data have been given in table 1, 2, 3, 4, 5 and 6 .

\section{Growth parameters}

The plant height at first flower appearance was significantly higher in treatment with $\mathrm{M}_{3}$ combination of media - Red soil + Coco peat + Vermicompost (1:1:1) and $\mathrm{B}_{2}$ bio fertilizer (VAM) (Vesicular Arbuscular Mycorrhiza) $(22.27 \mathrm{~cm})$ due to good aeration and better water retentive capabilities of cocopeat resulted in faster growth (Maria shaila, (2000) in gerbera), also due to vermicompost as it was a rich source of readily available macronutrients and chelated form of micronutrients like $\mathrm{Fe}$ and $\mathrm{Zn}$ ( Elizabeth George (2012) in gerbera) and the maximum plant height at flower appearance was recorded significantly because of the bio fertilizer (VAM) (Vesicular Arbuscular Mycorrhiza) might be due to association with plant roots, resulted in nutrients availability for diffusion of phosphate ion and increased the surface area for absorption of nutrients such as N, K, Mn and Zn (Praveen Kumar (2007) in gerbera). Significantly the highest value of plant height at flower harvesting stage was recorded in $\mathrm{M}_{3}$ combination of media - Red soil + Coco peat + Vermicompost (1:1:1) with $\mathrm{B}_{2}$ bio fertilizer (VAM) (Vesicular Arbuscular Mycorrhiza) $(24.97 \mathrm{~cm})$ and it was significantly lower in $\mathrm{M}_{5}$ combination of media - control (Red soil only) with $\mathrm{B}_{1}$ bio fertilizer (PSB) (Phosphate Solubilizing Bacteria) $(14.39 \mathrm{~cm})$ which might be due to more availability of nutrients, favoured stem elongation, ultimately resulted in increased cell division at sub apical meristem. Similar results were also reported by Chauhan et al., (2014), Praveen Kumar (2007) and Barreto Maria Shaila (2000) in gerbera. The maximum value of plant spread at first flower appearance in East - West direction and North - South direction was recorded significantly in $\mathrm{M}_{3}$ combination of media - Red soil + Coco peat + Vermicompost (1:1:1) with $\mathrm{B}_{2}$ bio fertilizer (VAM) (Vesicular Arbuscular Mycorrhiza) (51.92 $\mathrm{cm}),(54.94 \mathrm{~cm})$ respectively due to higher plant height of this treatment as compared to others. Moreover it might be due to better moisture retention capacity, availability of sufficient nutrients and good aeration. The findings are in accordance with the results of Jawaharlal et al., (2001) in Anthurium, Chauhan et al., (2014) and Praveen Kumar (2007) in gerbera whereas it was significantly lower in $\mathrm{M}_{5}$ combination of media - control (Red soil only) with $\mathrm{B}_{1}$ bio fertilizer (PSB) (Phosphate Solubilizing Bacteria) (29.51cm) $(31.85 \mathrm{~cm})$ respectively. Plant spread at first 
flower harvesting stage in East - West direction and North - South direction was recorded significantly maximum value in $\mathrm{M}_{3}$ combination of media - Red soil + Cocopeat + Vermicompost (1:1:1) with $\mathrm{B}_{2}$ bio fertilizer (VAM) (Vesicular Arbuscular Mycorrhiza) $(53.98 \mathrm{~cm}),(57.94 \mathrm{~cm})$ respectively. While it was significantly lower in $\mathrm{M}_{5}$ combination of media - control (Red soil only) with $\mathrm{B}_{1}$ bio fertilizer (PSB) (Phosphate Solubilizing Bacteria) $(30.85 \mathrm{~cm}),(34.85 \mathrm{~cm})$ respectively. These results were due to the same treatment recorded maximum value of plant spread at first flower appearance East-West and North - South direction.

Table.1 Effect of different combinations of media and bio fertilizers on growth of gerbera cv. Natasha under protected conditions

\begin{tabular}{|c|c|c|c|c|c|c|}
\hline \multirow[t]{2}{*}{ Media(M) / Treatments } & \multicolumn{3}{|c|}{$\begin{array}{l}\text { Plant height at first flower appearance } \\
\qquad(\mathbf{c m})\end{array}$} & \multicolumn{3}{|c|}{$\begin{array}{l}\text { Plant height at flower harvesting stage } \\
(\mathbf{c m})\end{array}$} \\
\hline & B1 & B2 & Mean & $\mathbf{B}_{1}$ & $\mathbf{B}_{2}$ & Mean \\
\hline M1 & 12.99 & 13.88 & $13.44^{\mathrm{d}}$ & 15.30 & 16.18 & $15.74^{d}$ \\
\hline M2 & 15.04 & 16.06 & $15.56^{\mathrm{c}}$ & 17.37 & 18.37 & $17.87^{\mathrm{c}}$ \\
\hline M3 & 20.03 & 22.27 & $21.15^{\mathrm{a}}$ & 22.37 & 24.97 & $23.67^{\mathrm{a}}$ \\
\hline M4 & 17.50 & 18.86 & $18.18^{b}$ & 19.82 & 21.18 & $20.50^{b}$ \\
\hline M5 & 12.03 & 12.74 & $12.39^{\mathrm{e}}$ & 14.39 & 15.05 & $14.72^{e}$ \\
\hline \multirow{2}{*}{ Mean } & $15.52^{b}$ & $16.76^{\mathrm{a}}$ & & $17.85^{\mathrm{b}}$ & $19.15^{\mathrm{a}}$ & \\
\hline & SEm \pm & CD@ $9 \%$ & & SEm \pm & CD@ 5\% & \\
\hline Media (M) & 0.17 & 0.52 & & 0.19 & 0.58 & \\
\hline Bio fertilizer (B) & 0.11 & 0.33 & & 0.12 & 0.37 & \\
\hline $\mathbf{M} \times \mathbf{B}$ & 0.25 & 0.74 & & 0.27 & 0.82 & \\
\hline
\end{tabular}

$\mathrm{M}_{1}$ - Red soil + Coco peat (1:1)

$\mathrm{M}_{2}$ - Red soil + Vermicompost (1: 1)

$\mathrm{B}_{1}$ - PSB (Phosphate Solubilizing Bacteria)

$\mathrm{M}_{3}$ - Red soil + Coco peat + Vermicompost (1:1:1)

$\mathbf{M}_{4}$ - Red soil + Coco peat + Vermicompost (2:1:1)

$\mathrm{M}_{5}$ - Control (Red soil only)

Table.2 Effect of different combinations of media and bio fertilizers on growth of

\begin{tabular}{|c|c|c|c|c|c|c|}
\hline $\begin{array}{l}\text { Media }(M) / \\
\text { Treatments }\end{array}$ & \multicolumn{3}{|c|}{$\begin{array}{l}\text { Plant spread at first flower appearance } \\
\text { East-West direction }(\mathrm{cm})\end{array}$} & \multicolumn{3}{|c|}{$\begin{array}{l}\text { Plant spread at first flower appearance } \\
\text { North-South direction }(\mathrm{cm})\end{array}$} \\
\hline & $\mathbf{B}_{1}$ & $\mathbf{B}_{2}$ & Mean & $\mathbf{B}_{1}$ & $\mathbf{B}_{2}$ & Mean \\
\hline $\mathbf{M}_{1}$ & 33.41 & 35.53 & $34.47^{d}$ & 36.04 & 38.10 & $37.07^{d}$ \\
\hline $\mathbf{M}_{2}$ & 38.15 & 41.43 & $39.79^{c}$ & 40.78 & 44.07 & $42.42^{c}$ \\
\hline $\mathbf{M}_{3}$ & 47.49 & 51.92 & $49.70^{a}$ & 49.86 & 54.94 & $52.40^{\mathrm{a}}$ \\
\hline $\mathbf{M}_{4}$ & 43.49 & 45.38 & $44.44^{b}$ & 46.14 & 48.20 & $47.17^{b}$ \\
\hline$M_{5}$ & 29.51 & 31.37 & $30.44^{\mathrm{e}}$ & 31.85 & 34.04 & $32.94^{\mathrm{e}}$ \\
\hline \multirow[t]{2}{*}{ Mean } & $38.41^{b}$ & $41.13^{a}$ & & $40.93^{b}$ & $43.87^{\mathrm{a}}$ & \\
\hline & SEm \pm & CD@ $9 \%$ & & SEm \pm & CD@ $0 \%$ & \\
\hline Media (M) & 0.26 & 0.78 & & 0.33 & 0.99 & \\
\hline Bio fertilizer (B) & 0.17 & 0.49 & & 0.21 & 0.63 & \\
\hline M $\times$ B & 0.37 & 1.10 & & 0.47 & 1.40 & \\
\hline $\begin{array}{l}\mathrm{M}_{1}-\text { Red soil + Coco } \\
\mathrm{M}_{2}-\text { Red soil + Verm } \\
\mathrm{M}_{3}-\text { Red soil + Coco } \\
\mathrm{M}_{4}-\text { Red soil + Coco } \\
\mathrm{M}_{5}-\text { Control (Red soi }\end{array}$ & $\begin{array}{l}(1: 1) \\
\text { lpost }(1: 1) \\
+ \text { Vermico } \\
+ \text { Vermico } \\
\text { y) }\end{array}$ & $\begin{array}{r}\mathrm{B}_{1} \\
\mathrm{~B}_{2} \\
\text { st }(1: 1: 1) \\
\text { st }(2: 1: 1)\end{array}$ & $\begin{array}{l}3 \text { (Phospl } \\
\text { M (Vesicl }\end{array}$ & $\begin{array}{l}\text { Solubilizin } \\
\text { Arbuscular }\end{array}$ & $\begin{array}{l}\text { cteria) } \\
\text { corrhiza) }\end{array}$ & \\
\hline
\end{tabular}


Table.3 Effect of different combinations of media and bio fertilizers on growth of gerbera cv. Natasha under protected conditions

\begin{tabular}{|c|c|c|c|c|c|c|}
\hline \multirow[t]{2}{*}{$\begin{array}{l}\text { Media (M) / } \\
\text { Treatments }\end{array}$} & \multicolumn{3}{|c|}{$\begin{array}{l}\text { Plant spread at flower harvesting } \\
\text { stage East-West direction }(\mathrm{cm})\end{array}$} & \multicolumn{3}{|c|}{$\begin{array}{l}\text { Plant spread at flower harvesting } \\
\text { stage North-South direction }(\mathrm{cm})\end{array}$} \\
\hline & $\mathbf{B}_{1}$ & $\mathbf{B}_{2}$ & Mean & $\mathbf{B}_{1}$ & $\mathbf{B}_{2}$ & Mean \\
\hline $\mathbf{M}_{1}$ & 35.04 & 37.10 & $36.07^{d}$ & 39.04 & 41.10 & $40.07^{d}$ \\
\hline $\mathbf{M}_{2}$ & 39.78 & 43.06 & $41.42^{c}$ & 43.78 & 47.07 & $45.42^{c}$ \\
\hline $\mathbf{M}_{3}$ & 48.85 & 53.98 & $51.41^{\mathrm{a}}$ & 53.19 & 57.94 & $55.56^{\mathrm{a}}$ \\
\hline $\mathbf{M}_{4}$ & 45.15 & 47.20 & $46.18^{b}$ & 49.14 & 51.20 & $50.17^{b}$ \\
\hline $\mathbf{M}_{5}$ & 30.85 & 33.04 & $31.94^{\mathrm{e}}$ & 34.85 & 37.04 & $35.94^{\mathrm{e}}$ \\
\hline \multirow[t]{2}{*}{ Mean } & $39.93^{b}$ & $42.88^{\mathrm{a}}$ & & $43.99^{b}$ & $46.87^{\mathbf{a}}$ & \\
\hline & SEm \pm & CD@ $9 \%$ & & SEm \pm & CD@ $9 \%$ & \\
\hline Media (M) & 0.34 & 1.00 & & 0.42 & 0.88 & \\
\hline Bio fertilizer (B) & 0.21 & 0.63 & & 0.26 & 0.56 & \\
\hline M $\times$ B & 0.48 & 1.42 & & 0.59 & 1.24 & \\
\hline $\begin{array}{l}M_{1} \text { - Red soil + Coco pe } \\
M_{2} \text { - Red soil + Vermico } \\
M_{3} \text { - Red soil + Coco pe } \\
M_{4} \text { - Red soil + Coco pe } \\
M_{5} \text { - Control (Red soil ol }\end{array}$ & $\begin{array}{l}t(1: 1) \\
\text { npost }(1: 1) \\
t+\text { Vermicon } \\
t+\text { Vermicon }\end{array}$ & $\begin{array}{l}\mathrm{B}_{1}-\mathrm{P} \\
\mathrm{B}_{2}- \\
\text { st }(1: 1: 1) \\
\text { st }(2: 1: 1)\end{array}$ & $\begin{array}{l}\text { (Phosphate } \\
\text { I (Vesicular }\end{array}$ & $\begin{array}{l}\text { Solubilizing } \mathrm{F} \\
\text { Arbuscular } \mathrm{N}\end{array}$ & $\begin{array}{l}\text { teria) } \\
\text { orrhiza) }\end{array}$ & \\
\hline
\end{tabular}

Table.4 Effect of different combinations of media and bio fertilizers on growth of gerbera cv. Natasha under protected conditions

\begin{tabular}{|c|c|c|c|c|c|c|}
\hline \multirow{2}{*}{$\begin{array}{l}\text { Media }(\mathbf{M}) / \\
\text { Treatments }\end{array}$} & \multicolumn{3}{|c|}{ Number of leaves per plant } & \multicolumn{3}{|c|}{ Leaf area at final harvest $(\mathrm{cm} 2)$} \\
\hline & $\mathbf{B}_{1}$ & $\mathbf{B}_{2}$ & Mean & $\mathbf{B}_{1}$ & $\mathbf{B}_{2}$ & Mean \\
\hline $\mathbf{M}_{1}$ & 22.15 & 24.16 & $23.16^{d}$ & 43.41 & 50.45 & $46.93^{d}$ \\
\hline $\mathbf{M}_{2}$ & 26.11 & 28.16 & $27.14^{\mathrm{c}}$ & 63.07 & 74.11 & $68.60^{c}$ \\
\hline $\mathbf{M}_{3}$ & 33.45 & 37.29 & $35.37^{\mathrm{a}}$ & 112.10 & 120.45 & $116.28^{\mathrm{a}}$ \\
\hline $\mathbf{M}_{4}$ & 30.26 & 31.57 & $30.92^{b}$ & 82.43 & 102.10 & $92.27^{b}$ \\
\hline $\mathbf{M}_{5}$ & 18.13 & 20.21 & $19.17^{\mathrm{e}}$ & 35.08 & 43.12 & $39.10^{\mathrm{e}}$ \\
\hline \multirow[t]{2}{*}{ Mean } & $26.02^{b}$ & $28.28^{\mathrm{a}}$ & & $67.22^{b}$ & $78.05^{\mathrm{a}}$ & \\
\hline & SEm \pm & CD@ $@ 5 \%$ & & SEm \pm & CD@ $5 \%$ & \\
\hline Media (M) & 0.25 & 0.74 & & 1.10 & 3.30 & \\
\hline Bio fertilizer (B) & 0.16 & 0.47 & & 0.70 & 2.90 & \\
\hline $\mathbf{M} \times \mathbf{B}$ & 0.35 & 1.04 & & 1.56 & 4.67 & \\
\hline
\end{tabular}

$\mathrm{M}_{1}-$ Red soil + Coco peat $(1: 1)$

$\mathrm{B}_{1}$ - PSB (Phosphate Solubilizing Bacteria)

$\mathrm{M}_{2}$ - Red soil + Vermicompost (1: 1)

$\mathrm{B}_{2}$ - VAM (Vesicular Arbuscular Mycorrhiza)

$\mathrm{M}_{3}-$ Red soil + Coco peat + Vermicompost (1:1:1)

$\mathrm{M}_{4}$ - Red soil + Coco peat + Vermicompost $(2: 1: 1)$

$\mathrm{M}_{5}$ - Control (Red soil only) 
Table.5 Effect of different combinations of media and bio fertilizers on Root growth of gerbera cv. Natasha under protected conditions

\begin{tabular}{|c|c|c|c|c|c|c|}
\hline \multirow{2}{*}{$\begin{array}{l}\text { Media }(\mathrm{M}) \text { / } \\
\text { Treatments }\end{array}$} & \multicolumn{3}{|c|}{ Number of roots per plant } & \multicolumn{3}{|c|}{ Length of the primary root $(\mathrm{cm})$} \\
\hline & $\mathbf{B}_{1}$ & $\mathbf{B}_{2}$ & Mean & $\mathbf{B}_{1}$ & $\mathbf{B}_{2}$ & Mean \\
\hline $\mathbf{M}_{1}$ & 45.15 & 46.83 & $45.99^{d}$ & 37.49 & 39.83 & $38.66^{d}$ \\
\hline $\mathbf{M}_{2}$ & 49.11 & 50.83 & $49.97^{c}$ & 42.11 & 43.83 & $42.97^{c}$ \\
\hline $\mathbf{M}_{3}$ & 56.45 & 60.29 & $58.37^{\mathrm{a}}$ & 49.45 & 53.29 & $51.37^{\mathrm{a}}$ \\
\hline $\mathbf{M}_{4}$ & 53.26 & 54.57 & $53.92^{b}$ & 46.92 & 47.57 & $47.25^{b}$ \\
\hline $\mathbf{M}_{5}$ & 41.13 & 42.21 & $41.67^{\mathrm{e}}$ & 34.13 & 35.21 & $34.67^{\mathrm{e}}$ \\
\hline \multirow[t]{2}{*}{ Mean } & $49.02^{b}$ & $50.95^{\mathrm{a}}$ & & $42.02^{b}$ & $43.95^{\mathbf{a}}$ & \\
\hline & $\mathrm{SEm} \pm$ & CD@ $@ 5 \%$ & & SEm \pm & CD@ $@ 5 \%$ & \\
\hline Media (M) & 0.25 & 0.73 & & 0.26 & 0.78 & \\
\hline Bio fertilizer (B) & 0.16 & 0.46 & & 0.16 & 0.49 & \\
\hline $\mathbf{M} \times \mathbf{B}$ & 0.35 & 1.04 & & 0.37 & 1.10 & \\
\hline $\begin{array}{l}M_{1}-\text { Red soil + Cc } \\
M_{2}-\text { Red soil + Ve } \\
M_{3}-\text { Red soil + Cc } \\
M_{4}-\text { Red soil + Cc } \\
M_{5} \text { - Control (Red }\end{array}$ & $\begin{array}{l}\text { at }(1: 1) \\
\text { ompost }(1: \\
\text { at + Vermi } \\
\text { at + Vermi } \\
\text { nly) }\end{array}$ & $\begin{array}{l}\text { post }(1: 1: 1) \\
\text { post }(2: 1: 1)\end{array}$ & $\begin{array}{l}\text { B (Phos } \\
\text { AM (Vesi }\end{array}$ & $\begin{array}{l}\text { Solubilizing } \\
\text { Arbuscular }\end{array}$ & $\begin{array}{l}\text { eria) } \\
\text { rrhiza) }\end{array}$ & \\
\hline
\end{tabular}

Table.6 Effect of different combinations of media and bio fertilizers on Root growth of gerbera cv. Natasha under protected conditions

\begin{tabular}{|c|c|c|c|c|c|c|}
\hline \multirow{2}{*}{$\begin{array}{l}\text { Media }(\mathrm{M}) / \\
\text { Treatments }\end{array}$} & \multicolumn{3}{|c|}{ Fresh weight of the plant (g) } & \multicolumn{3}{|c|}{ Root to shoot ratio (\%) } \\
\hline & $\mathbf{B}_{1}$ & $\mathbf{B}_{2}$ & Mean & $\mathbf{B}_{1}$ & $\mathbf{B}_{2}$ & Mean \\
\hline $\mathbf{M}_{1}$ & 123.75 & 130.78 & $127.26^{d}$ & 0.72 & 0.81 & $0.77^{d}$ \\
\hline $\mathbf{M}_{2}$ & 143.40 & 154.45 & $148.93^{c}$ & 0.87 & 0.89 & $0.88^{\mathrm{c}}$ \\
\hline $\mathbf{M}_{3}$ & 192.44 & 202.78 & $197.61^{\mathrm{a}}$ & 0.93 & 0.93 & $0.93^{\mathrm{a}}$ \\
\hline $\mathbf{M}_{4}$ & 162.77 & 182.44 & $172.60^{\mathbf{b}}$ & 0.91 & 0.91 & $0.91^{\mathbf{b}}$ \\
\hline $\mathbf{M}_{5}$ & 115.42 & 123.45 & $119.44^{\mathrm{e}}$ & 0.68 & 0.69 & $0.68^{\mathrm{e}}$ \\
\hline \multirow[t]{2}{*}{ Mean } & $147.55^{b}$ & $158.78^{\mathrm{a}}$ & & $0.82^{b}$ & $0.85^{\mathrm{a}}$ & \\
\hline & SEm \pm & CD@ $9 \%$ & & SEm \pm & $\begin{array}{c}\text { CD@ } \\
5 \%\end{array}$ & \\
\hline Media (M) & 1.20 & 3.58 & & 0.01 & 0.03 & \\
\hline Bio fertilizer (B) & 0.76 & 2.27 & & 0.01 & 0.02 & \\
\hline $\mathbf{M} \times \mathbf{B}$ & 1.70 & 5.07 & & 0.02 & 0.05 & \\
\hline \multicolumn{7}{|c|}{$\begin{array}{lc}M_{1}-\text { Red soil + Coco peat }(1: 1) & B_{1}-\text { PSB } \\
M_{2}-\text { Red soil + Vermicompost }(1: 1) & B_{2}-\text { VAM } \\
M_{3} \text { - Red soil + Coco peat + Vermicompost }(1: 1: 1) \\
M_{4} \text { - Red soil + Coco peat + Vermicompost }(2: 1: 1) \\
M_{5} \text { - Control (Red soil only) }\end{array}$} \\
\hline
\end{tabular}


Our results are comparable with that of Pawar et al., (2002) in Anthurium, Praveen Kumar, (2007) and Chauhan et al., (2014) in gerbera. Number of leaves per plant was recorded significantly the highest value (37.29) in $\mathrm{M}_{3}$ combination of media - Red soil + Coco peat + Vermicompost (1:1:1) with $\mathrm{B}_{2}$ bio fertilizer (VAM) (Vesicular Arbuscular Mycorrhiza), while it was significantly lowest in $\mathrm{M}_{5}$ combination of media - control (Red soil only) with $\mathrm{B}_{1}$ bio fertilizer (PSB) (Phosphate Solubilizing Bacteria) (18.13). Which was due to the same treatment recorded luxurious vegetative growth and maximum plant spread rather than other treatments and also due to the availability of more nutrients, led to more leaf number. The results are in conformity with the findings of Chauhan et al., (2014), Praveen Kumar, (2007) and Elizabeth George (2012) in gerbera. Leaf area at final harvest was recorded significantly maximum value in $\mathrm{M}_{3}$ combination of media - Red soil + Coco peat + Vermicompost (1:1:1) with $\mathrm{B}_{2}$ bio fertilizer (VAM) (Vesicular Arbuscular Mycorrhiza) (120.45 $\left.\mathrm{cm}^{2}\right)$, while it was significantly minimum in $\mathrm{M}_{5}$ combination of media - control (Red soil only) with $\mathrm{B}_{1}$ bio fertilizer (PSB) (Phosphate Solubilizing Bacteria) $\left(35.08 \mathrm{~cm}^{2}\right)$ due to the same treatment recorded maximum values in plant spread parameter in both directions rather than other treatments and also due to nitrogen being a constituent of chlorophyll might have increased the leaf area Subhankar Saha et al., (2018) in gerbera.

\section{Root parameters}

More number of roots per plant was recorded significantly in $\mathrm{M}_{3}$ combination of Media Red soil + Coco peat + Vermicompost (1:1:1) with $\mathrm{B}_{2}$ bio fertilizer (VAM) (Vesicular Arbuscular Mycorrhiza) (60.29), while it was significantly less in $\mathrm{M}_{5}$ combination of media - control (Red soil only) with $\mathrm{B}_{1}$ bio fertilizer (PSB) (Phosphate Solubilizing Bacteria)
(41.13). This might be due to the luxurious vegetative growth of this treatment rather than others. Moreover it was due to the less compact nature media, permitted more space for root development. The results are in accordance with the findings of Barreto Maria shaila (2000) in gerbera. The highest length of the primary root was registered significantly in $\mathrm{M}_{3}$ combination of media - Red soil + Coco peat + Vermicompost $(1: 1: 1))$ with $\mathrm{B}_{2}$ bio fertilizer (VAM) (Vesicular Arbuscular Mycorrhiza) (53.29 cm), while it was significantly lowest in $\mathrm{M}_{5}$ combination of media - control (Red soil only) with $\mathrm{B}_{1}$ bio fertilizer (PSB) (Phosphate Solubilizing Bacteria) $(34.13 \mathrm{~cm})$. This was due to the less compact nature media, permitted more space for root development. The present findings are comparable with that of Barreto Maria shaila (2000) in gerbera. The data enunciated on fresh weight of the plant revealed that $\mathrm{M}_{3}$ combination of media - Red soil + Coco peat + Vermicompost (1:1:1) with $\mathrm{B}_{2}$ bio fertilizer (VAM) (Vesicular Arbuscular Mycorrhiza) recorded significantly maximum value (202.78 g), while it was significantly minimum in $\mathrm{M}_{5}$ combination of media control (Red soil only) with $\mathrm{B}_{1}$ bio fertilizer (PSB) (Phosphate Solubilizing Bacteria) (115.42 g) which might be due to the same treatment registered better values in terms of growth and root parameters as compared to rest of the treatments. The present investigation was in consistent with other reports of Barreto Maria shaila (2000) in gerbera. Significantly the highest value of Root to shoot ratio was recorded in $M_{3}$ combination of media - Red soil + Coco peat + Vermicompost (1:1:1) with $\mathrm{B}_{2}$ bio fertilizer (VAM) (Vesicular Arbuscular Mycorrhiza) $(0.93 \%)$, while it was significantly lowest in $\mathrm{M}_{5}$ combination of media - control (Red soil only) with $\mathrm{B}_{1}$ bio fertilizer PSB (Phosphate Solubilizing Bacteria) (0.68 \%) which was due to the same treatment recorded more root weight, resulted in more absorption of 
nutrition from the media led to more root to shoot ratio. These findings are in line with the reports of Barreto Maria shaila (2000) in gerbera.

\section{References}

Barreto Maria shaila. 2000. Studies on the effects of different Substrate media on growth, flower quality and vase life of gerbera under Polyhouse conditions. M. Sc. (Agri.) Thesis, Mahatma phule krishi vidyapeeth, Pune.

Chauhan, R.V., Varu, D.K., Kava, K.P. and Savaliya, V.M. 2014. Effect of different media on growth, flowering and cut flower yield of gerbera under protected condition. The Asian journal of Horticulture. 9: 228-231.

Elizabeth George. 2012. Integrated nutrient management on growth, flower yield and postharvest quality of gerbera (gerbera jamesonii bolus.) cv. Galileo red under poly house condition. University of Agricultural sciences, Bangalore, P.hd thesis.

Jawaharlal, M., PremJoshua, J., Arumugam, J., Arumugam, T., Subramanian, S. and Vijaykumar, M. 2001. Standardization of growing media for Anthurium (Anthurium andreqnum) cv. Temptation under shade net house. South Indian Horticulture. 46: 323-325.

Panse, V.G and Sukhatme, P.V. 1985.Statistical methods for agricultural workers. Indian Council Of Agricultural Research, New Delhi, India.

Pawar, G.M., Patil, M.T. and Gaikwad, A.M. 2002. Effect of substrates on anthurium culture. "Floriculture research trend in India," Proceedings of the national symposium on Indian floriculture in the new millennium, Lal Baugh, Bangalore. 326-327.

Praveenkumar. 2007. Integrated nutrient management in gerbera (gerbera iamesonii L.) under polyhouse conditions". M.Sc thesis, Horticulture mahatma phule krishi vidyapeeth, Rahuri.

Subhankara saha, Madhumitha Choudary Talukdar and Deepa Borbora.2018. Effect of growing media and depth on rooftop cultivation of Gerbera (Gerbera jamesonii Bolus) cv. Red Gem. International Journal of Current Microbiology and Applied Sciences. 7(5): 189-193.

\section{How to cite this article:}

Swarupa, N., D. Lakshminarayana, P. Prasanth and Saida Naik, D. 2019. Influence of Different Combinations of Media and Bio Fertilizers on Growth of Gerbera cv. Natasha under Protected Conditions. Int.J.Curr.Microbiol.App.Sci. 8(04): 2797-2804.

doi: https://doi.org/10.20546/ijcmas.2019.804.326 